\title{
PENEGAKAN HUKUM PIDANA DALAM MENANGGULANGI TINDAK PIDANA LINGKUNGAN MELALUI PENDEKATAN RESTORATIVE JUSTICE
}

\author{
Iman Imanuddin \\ Kementerian Politik Hukum dan Keamanan \\ Imanrss007@gmail.com \\ DOI: https://doi.org/10.29313/sh.v16i2.4882
}

\begin{abstract}
ABSTRAK
Permasalahan menerapkan restorative justice terhadap kasus tindak pidana lingkungan masih menjadi persoalan yuridis terkait apakah semua tindak pidana lingkungan dapat diselesaikan secara restoratif, model restoratif yang cocok dan akibat hukumnya terhadap status kasus. Penelitian ini bertujuan menemukan model restorative justice yang dapat diterapkan terhadap tindak pidana lingkungan dan untuk menentukan akibat hukum penerapan restorative justice terhadap status perkara tindak pidana lingkungan. Metode penelitian menggunakan pendekatan yuridis normatif dengan data sekunder dan studi kepustakaan serta menggunakan teknik analisis data secara kualitatif. Hasil penelitian menunjukkan (1) Model Restorative Justice yang dimungkinkan dapat diterapkan dalam penegakan hukum pidana untuk menanggulangi tindak pidana lingkungan hidup adalah model Pertemuan Restoratif (Restorative Conferencing), sebuah model yang membutuhkan partisipasi dari pelaku, korban lingkungan), mediator, penyidik Polri dan PPNS secara sukarela untuk mencari kesepakatan perdamaian. (2) Penerapan restorative justice dengan model pertemuan restoratif, menimbulkan akibat hukum terhadap status perkara tindak pidana lingkungan berupa penghentian penyidikan untuk menghindari sanksi pidana sepanjang memenuhi syarat materil dan formil.
\end{abstract}

Kata Kunci: Restoratif Justice, Lingkungan Hidup, Akibat Hukum.

\section{ABSTRACT}

The existence of a banking institution has a positive impact, but also the existence of a banking institution can have a negative impact where the banking institution as a corporation can be a criminal offense that is detrimental to the wider community but is often not touched by law. The results show that the corporate criminal liability system has been legitimized and justified by several doctrines or theories namely: identification theory, strict liability theory, vicarious liability doctrine, the corporate culture model or company culture theory, doctrine of aggregation, and reactive corporate fault. If it is related to the subject matter examined, the corporate criminal liability system as legitimized and justified by various theories can be applied to banking institutions. Thus, banks are considered to be able to commit criminal acts and bear criminal liability. However, the criminal liability system for banking 
institutions cannot be implemented because the banking law is still dominated by the principle of "societas delinquere non potest" and collided with the principle of legality.

Keywords: Exoneration Clause, Binding Strength, Contracting Freedom

\section{A. PENDAHULUAN}

\section{Latar Belakang Masalah}

Penegakan hukum lingkungan memerlukan model pendekatan yang mampu mengakomodir kepentingan lingkungan hidup sebagai korban kejahatan lingkungan. Hukum tidak bisa memandang alam hanya sebagai objek tetapi juga subjek yang perlu dilindungi kelestariannya. Mengingat selama ini penegakan hukum lingkungan dalam sistem peradilan pidana lebih banyak menuntut pertanggungjawaban pelaku baik individu maupun korporasi tetapi seringkali mengabaikan kelestarian lingkungan yang rusak dan tercemar. ${ }^{1}$

Dilihat dari praktek penegak hukum meskipun asasnya adalah ultimum remidium tetapi penegak hukum cenderung lebih banyak menggunakan instrumen hukum pidana daripada menerapkan instrumen hukum lainnya. Padahal penggunaan hukum pidana dalam perkara lingkungan hidup sejauh mungkin harus dihindari kecuali instrumen hukum administrasi dan perdata tidak dapat dijalankan secara efektif. $^{2}$

Penggunaan sanksi pidana terhadap tindakan pencemaran dan perusakan lingkungan hidup dalam realitasnya tidak menunjukkan daya jera terhadap pelaku individu maupun korporasi tetapi sebaliknya, trend kejahatan lingkungan justru semakin banyak dengan berbagai bentuk seperti pencemaran limbah, illegal logging, pencemaran udara dan sebagainya. ${ }^{3}$ Menegakkan aturan hukum lingkungan tidak harus dengan melakukan penegakan hukum pidana yang

\footnotetext{
${ }^{1}$ Sudharto P Hadi dan Adji Samekto, Dimensi Lingkungan dalam Bisnis Kajian Tanggung Jawab Sosial Perusahaan pada Lingkungan, Badan Penerbit Undip Semarang, 2007, hlm. 37.

${ }^{2}$ Absori, Hukum Lingkungan dan Pemberdayaan Masyarakat, Makalah Seminar Legal Hermenutics Sebagai Alternatif Kajian Hukum, Makalah FH Undip, 24 November 2007, hlm. 21.

${ }^{3}$ Muhammad Akib, Wewenang Kelembagaan Pengelolaan Lingkungan Hidup di Era Otonomi Daerah, Jurnal Media Hukum UMY Vol. 19 No. 2 Desember 2012, hlm. 112
} 
bertujuan untuk menghukum tetapi menjalankan hukum lingkungan sebaiknya harus lebih diarahkan pada pemulihan kelestarian lingkungan seperti semula. Itu sebabnya Undang-undang No. 32 Tahun 2009

Tentang Perlindungan dan Pengelolaan Lingkungan Hidup mengutamakan penegakan hukum administrasi dan perdata daripada hukum pidana. Mengingat kedua instrumen hukum tersebut memungkinkan untuk menerapkan sanksi yang mengarah pada pemulihan lingkungan. ${ }^{4}$

Salah satu konsep yang tepat untuk mengatasi berbagai masalah penegakan hukum lingkungan sebagaimana digambarkan di atas adalah Pendekatan restorative justice system. ${ }^{5}$ Pendekatan restorative justice system dalam penyelesaian perkara pidana (penal) dianggap sebagai suatu metode baru, meskipun pola-pola yang digunakan sebagian besar telah mengakar dalam nilai-nilai kearifan lokal masyarakat primitif. Konsep pendekatan restorative justice merupakan suatu pendekatan yang lebih menitikberatkan pada kondisi terciptanya keadilan dan keseimbangan bagi pelaku tindak pidana serta korbannya. ${ }^{6}$

Mekanisme tata acara dan peradilan pidana yang berfokus pada pemidanaan diubah menjadi proses dialog dan mediasi untuk menciptakan kesepakatan atas penyelesaian perkara pidana yang lebih adil dan seimbang bagi pihak korban dan pelaku. ${ }^{7}$ Pendekatan keadilan restoratif bisa diasumsikan sebagai pergeseran paling mutakhir dari berbagai model dan mekanisme yang bekerja

\footnotetext{
${ }^{4}$ Siti Sundari Rangkuti, Kesamaan Persepsi Terhadap Penegakan Hukum Lingkungan, Majalah FH Unair, No. 5 Tahun IX Oktober 1994, hlm. 18.

${ }^{5}$ Tony F. Marsall menjelaskan bahwa Keadilan restoratif adalah pendekatan pemecahan masalah kejahatan yang melibatkan para pihak sendiri, dan masyarakat umumnya, dalam hubungan aktif dengan badan-badan hokum (Restorative Justice is a problem-solving approach to crime which involves the parties themselves, and the community generally, in an active relationship with statutory agencies). Bandingkan, Marshall, Tony F. Restorative Justice an Overview. Home Office, Information \& Publications Group London, hlm. 5.

${ }^{6}$ Jecky Tengens, Selasa, 19 July 2011, Pendekatan Restorative Justice dalam Sistem Pidana Indonesia, Website Internet: http://hukumonline.com/berita/ baca/ lt4e25360a422c2/pendekatanrestorative-justice-

dalam-sistem-pidana-indonesia, diakses tanggal 25 September 2017.

${ }^{7}$ Phillipe Nonet dan Philip Selznick, Law and Society Transition, Harper \& Row, New York, 1978, H124
} 
dalam sistem peradilan pidana untuk menangani perkara-perkara pidana pada saat ini. $^{8}$

Pendekatan keadilan restoratif merupakan sebuah pemikiran yang merespon pengembangan sistem peradilan pidana dengan menitikberatkan pada kebutuhan pelibatan masyarakat dan/atau korban yang selama ini tersisihkan dengan mekanisme yang bekerja pada sistem peradilan pidana yang ada pada saat ini. Di pihak lain pendekatan keadilan restoratif juga merupakan kerangka berfikir baru yang dapat digunakan dalam merespon suatu tindak pidana bagi penegak hukum. ${ }^{9}$

Pandangan retributive justice dalam penyelesaian perkara pidana dewasa ini sudah mulai banyak mendapat kritik karena tidak memberikan kepuasan bagi masyarakat khususnya korban karena retributive justice hanya memandang pelaku sebagai objek yang harus mendapat balasan sedangkan kepentingan hukum korban kurang mendapat perhatian. Dalam tindak pidana lingkungan aspek korban menjadi elemen yang menjadi perhatian utama karena lingkungan yang menjadi korban merupakan ekosistem yang menjadi tempat tinggal makhluk hidup, jika dalam penyelesaiannya hanya menitikberatkan pada penghukuman pelaku maka kepentingan terhadap perbaikan lingkungan akan terabaikan.

Meskipun restorative justice dipandang baik untuk diterapkan dalam kasus tindak pidana lingkungan masih ada sejumlah persoalan hukum yang menjadi perdebatan terkait apakah semua tindak pidana lingkungan dapat diselesaikan dengan restoratif, bagaimana cara atau metode yang digunakan untuk menerapkannya dalam sistem peradilan pidana dan bagaimana akibat hukum dari restorative justice terhadap status perkara lingkungan tersebut.

Apakah seluruh kasus lingkungan bisa diselesaikan dengan keadilan restoratif terutama kasus besar yang berdampak luas bagi masyarakat dan mungkin penyelesaian restoratif dapat memberikan keadilan bagi pelaku dan korban karena cara ini akan mengesampingkan sanksi pidana dan apakah pelaku jera bila tidak dijatuhi sanksi pidana. Peluang menerapkan pendekatan keadilan restoratif dalam

\footnotetext{
${ }^{8}$ Satjipto Rahardjo, Hukum Progresif Hukum yang Membebaskan, Jurnal Hukum Progresif, Program Doktor Ilmu Hukum Undip, Semarang, 2005, hlm. 16

9 Anna Ningsih, Pemukiman Kembali, Alternatif Ganti Kerugian bagi Masyarakat Korban Penggusuran, Jurnal Hukum Vol. XXXI No 3 Juli Semarang, 2003, hlm, 42. 
kasus tindak pidana lingkungan secara faktual dimungkinkan karena tindak pidana lingkungan menimbulkan korban bukan hanya dari anggota masyarakat saja tetapi lingkungan hidup itu sendiri, hanya secara hukum ada persoalan-persoalan yang membutuhkan jawaban secara akademis sehingga dalam penerapannya tidak menimbulkan masalah baru. ${ }^{10}$

Persoalan yang membutuhkan penelitian terkait penerapan restorative justice dalam tindak pidana lingkungan berkaitan dengan model restorative justice yang cocok diterapkan dan bagaimana akibat hukum yang ditimbulkan bilamana para pihak sepakat menyelesaikan dengan perdamaian. Persoalan lain adalah apakah restorative justice memungkinkan diterapkan untuk semua tindak pidana lingkungan, sejauh mana batasan tindak pidana lingkungan yang bisa diselesaikan secara restoratif.

\section{Identifikasi Masalah}

Artikel ini akan membahas 1. Bagaimana model restorative justice yang dapat diterapkan dalam penegakan hukum pidana untuk menanggulangi tindak pidana lingkungan sebagai upaya menjamin kelestarian lingkungan hidup, dengan mengarah pada akibat hukum penerapan restorative justice terhadap status tindak pidana lingkungan hidup untuk mengurangi penumpukan perkara dan menghindari sanksi pidana

\section{Metode Penelitian}

Metode penelitian dalam penulisan ini menggunakan pendekatan yuridis normatif karena mengkaji peraturan perundang-undangan yang mengatur klausul eksonerasi dalam Undang-Undang Perlindungan Konsumen dengan menggunakan data sekunder melalui teknik studi kepustakaan dan dianalisis secara kualitatif.

\section{B. PEMBAHASAN}

${ }^{10}$ Edi Setiadi, Sistem Peradilan Pidana, Materi Kuliah S2 Unisba, Bandung, 2016, hlm. 13. 
a. Model Restorative Justice yang Dapat Diterapkan dalam Penegakan Hukum Pidana Pidana untuk Menanggulangi Tindak Pidana Lingkungan Hidup Sebagai Upaya Menjamin Kelestarian Lingkungan

Salah satu konsep yang tepat untuk mengatasi berbagai kontroversi output dari proses hukum pidana yang dipandang tidak memuaskan dan tidak sesuai harapan masyarakat menimbulkan tawaran strategi baru bagaimana cara menanggulangi tindak pidana lingkungan yang semakin masif. Tawaran baru yang muncul dari pemikiran para ahli hukum adalah menerapkan konsep restorative justice system. Pendekatan restorative justice sistem dalam penyelesaian perkara pidana (penal) dianggap sebagai suatu metode baru, meskipun pola-pola yang digunakan sebagian besar telah mengakar dalam nilai-nilai kearifan lokal masyarakat primitif. ${ }^{11}$ Konsep pendekatan restorative justice merupakan suatu pendekatan yang lebih menitikberatkan pada kondisi terciptanya keadilan dan keseimbangan bagi pelaku tindak pidana serta korbannya. Mekanisme tata acara dan peradilan pidana yang berfokus pada pemidanaan diubah menjadi proses dialog dan mediasi untuk menciptakan kesepakatan atas penyelesaian perkara pidana yang lebih adil dan seimbang bagi pihak korban dan pelaku.

Restorative justice pada saat itu memang belum diatur dalam perundangundangan di Indonesia, namun Hakim menerapkannya dalam putusan yang dibuatnya. Hal ini dikarenakan Hakim tidak bisa menolak perkara yang harus diadilinya, sebagaimana dimaksud dalam Pasal 10 ayat (1) Undang-Undang No 48 Tahun 2009 tentang Kekuasaan Kehakiman, yaitu:

"Pengadilan dilarang menolak untuk memeriksa, mengadili, dan memutus suatu perkara yang diajukan dengan dalih bahwa hukum tidak ada atau kurang jelas, melainkan wajib untuk memeriksa dan mengadilinya".

Hal yang menarik dan menjadi pertanyaan apakah restorative justice ini merupakan hal yang baru atau memang sudah ada dan berjalan dalam sistem

\footnotetext{
${ }^{11}$ Menurut Braithwaite bahwa: "according to its proponent, restorative justice is not a new invention. Rather, it is a return to traditional pattern of dealing with conflict and crime that had been present in different cultures throughout human history”. Braithwaite, J. 2002, restorative justice and Responsive Regulation, oxford University Press, p. 1. Lihat juga Margarita Zernova, 2007, Restorative Justice, Ideals and Realities, Ashgate Publishing Limited, hlm. 7 
hukum di Indonesia. Jika melihat dalam peraturan perundang-undangan yang ada, jelas dan tegas belum ada yang mengatur tentang restorative justice. Namun melihat dari konsep restorative justice, tidak berbeda dengan penyelesaian peristiwa pidana dalam masyarakat hukum adat ada dua pendekatan penyelesaian peristiwa pidana yaitu aspek magis dan material. ${ }^{12}$

Aspek magis bertalian dengan upaya mengembalikan keseimbangan magis yang terganggu akibat peristiwa pidana yang diselenggarakan dalam bentuk upacara-upacara tertentu seperti menyediakan sesajen atau mengorbankan hewan sebagai "tebusan". Hal yang agak ekstrim adalah sanksi dalam bentuk mengeluarkan atau mengusir pelanggar dari lingkungan masyarakat hukum yang bersangkutan.

Aspek magis bertalian dengan upaya mengembalikan keseimbangan magis yang terganggu akibat peristiwa pidana yang diselenggarakan dalam bentuk upacara-upacara tertentu seperti menyediakan sesajen atau mengorbankan hewan sebagai "tebusan". Hal yang agak ekstrim adalah sanksi dalam bentuk mengeluarkan atau mengusir pelanggar dari lingkungan masyarakat hukum yang bersangkutan.

Aspek material berkaitan dengan upaya merukunkan kembali hubungan antara pelaku (keluarga pelaku) dan korban (keluarga korban). Hal inipun dilakukan dengan berbagai upacara perdamaian antara kedua belah pihak. Bentuk lain adalah kewajiban pelaku (keluarga pelaku) melakukan sesuatu, seperti pernyataan bersalah, meminta maaf, memberi kompensasi atau denda tertentu. Praktek hukum adat sangat memperhatikan kepentingan korban yang bersifat material atau immaterial. Praktik- praktik ini tidak lain "restorative justice" yang telah menjadi tradisi masyarakat hukum adat kita. ${ }^{13}$

Restorative Justice dalam tatanan peraturan perundang-undangan di Indonesia, belum diatur secara tegas. Menurut Setyo Utomo, tentang

\footnotetext{
12 Bagir Manan, Restorative Justice (Suatu Perkenalan), Majalah Hukum Varia Peradilan, Tahun XXI No. 247 Juni 2006), hlm. 8

13 Ibid.
} 
pengaturan tujuan pemidanaan, pedoman pemidanaan dan sanksi alternatif baru diatur dalam Rancangan Kitab Undang-undang Hukum Pidana, dimana terdapat konsep Restorative Justice. ${ }^{14}$

Restorative Justice telah lama diterapkan dalam masyarakat Indonesia. Contoh seorang pelaku yang menabrak orang lain yang menimbulkan cidera atau meninggal, tidak jarang serta merta berusaha memberi perhatian terhadap korban (keluarga korban). Cara-cara tersebut dilakukan dengan mengambil tanggungjawab pengobatan, memberi yang duka, meminta maaf, dan lainlain. Hal yang disebutkan di atas bisa juga dikatakan sebagai bentuk penghukuman atau pemidanaan terhadap pelaku atas apa yang telah dilakukannya. Hal tersebut sebagaimana yang diutarakan oleh Dinah Shelton yaitu: ${ }^{15}$

"This the essential of compensatory justice are: (1) the patties are treated as equal; (2) there is damage inflicted by one party on another; (3) remedy seeks to restore the victim to the condition he or she was in before the unjust activity occurred. Remedies this are designed to place an aggrieved party in the same position as he or she would have been had no injury occurred. to achieved this end by holder the wrongdoer responsible for providing the remedy served a morel need; on a practical level collective insurance can as easily make the victims whole."

Pemidanaan merupakan bagian penting dari hukum pidana yang justru sering menjadi dambaan, sorotan dan sekaligus momok yang menakutkan bagi sebagian besar masyarakat. Hal ini disebabkan masyarakat umumnya mengukur sejauh mana keseriusan penegak hukum menerapkan keadilan lewat seberapa besar dan seberapa pantas pemidanaan yang dijatuhkan. Restorative justice sebagai suatu bentuk perkembangan terakhir dari berbagai pemikiran tentang hukum pidana dan pemidanaan, sehingga saat ini masih menjadi suatu konsep yang diperdebatkan. ${ }^{16}$

\footnotetext{
${ }^{14}$ Setyo Utomo, Sistem Pemidanaan Dalam Hukum Pidana Yang Berbasis Restorative Justice.: Majalah

Hukum Nasional Nomor 01 Tahun 2011, BPHN), Jakarta, hlm 137-162

${ }^{15}$ Dinah Shelton, Remedies In International Human Rights Law (New York, Oxford University Press,

1999) sebagaimana dikutip oleh Artidjo Alkostar, Restorative Justice, (Jakarta. Varia Peradilan XXII No. .262, IKAHI, hlm. 9-10.

${ }^{16}$ Eva Achjani Zulfa (a), Pergeseran Paradigma Pemidanaan, Lubuk Agung, Bandung, 2011, hlm. 
Penerapan konsep restorative justice dalam tindak pidana lingkungan bukan konsep yang datang secara tiba-tiba melainkan berdasarkan berbagai pendapat yang dikemukakan ahli hukum. Konsep restorative justice bukan dalam praktik dimungkinkan diterapkan untuk kasus tindak pidana tertentu terutama yang dalam penyelesaiannya membutuhkan penggantian kerugian dan pemulihan. Tindak pidana lingkungan merupakan salah satu jenis tindak pidana yang menuntut pemulihan terhadap lingkungan yang rusak atau tercemar, hanya saja dilihat dari bentuknya tindak pidana lingkungan dipandang sebagai kejahatan serius yang perlu menggunakan sanksi pidana supaya memberikan efek jera.

Model pertemuan restoratif (restorative conferencing) dapat menjadi pilihan yang bisa digunakan sebagai sarana penyelesaian tindak pidana lingkungan. Beberapa dalil yang bisa digunakan untuk menerapkan model restorative justice dalam kasus lingkungan adalah:

1. Melibatkan partisipan yang lebih luas ketimbang mediasi pelaku-korban;

2. Mampu mengarahkan orientasi penyelesaian dalam bentuk ganti kerugian dan pemulihan kelestarian lingkungan hidup;

3. Mudah diterapkan pada setiap tahap proses peradilan pidana;

4. Model ini telah banyak dikembangkan di banyak negara untuk berbagai kejahatan.

Model ini banyak dikembangkan di banyak negara sejak tahun 1989 dan menciptakan alternatif baru untuk menanggapi kejahatan remaja, persoalan perlindungan anak dengan menempatkan lebih banyak otoritas pengambil keputusan tetapi tetap dengan memperhatikan masukan, pertimbangan serta kepentingan para pihak. Model ini dapat diterapkan pada kejahatan lingkungan yang selama ini terjadi di Indonesia dan ditangani oleh penyidik Polri dan PPNS lingkungan.

Model pertemuan restoratif (restorative conferencing) dapat menjadi sarana mempertemukan kepentingan pelaku, korban (masyarakat dan lingkungan) serta otoritas terkait seperti Kementerian Lingkungan, Dinas lingkungan 
Provinsi/kabupaten/kota dan penegak hukum untuk membentuk forum musyawarah mufakat (pertemuan restoratif) mencari jalan keluar atas kerusakan lingkungan yang diakibatkan perbuatan pelaku. Dengan menerapkan model ini efisiensi penegakan hukum lingkungan dapat dilakukan serta tidak memakan waktu yang lama dan berlarut-larut. Meski demikian untuk menghindari perbedaan pendapat yang tajam dalam model ini dan meminimalisasi kegagalan dalam pengambilan kesepakatan perlu dilibatkan pula seorang mediator yang terlatih dan mampu menghitung kerugian ekologis yang rusak dan tercemar akibat

tindak pidana lingkungan secara profesional, obyektif dan transparan. ${ }^{17}$

Pertemuan restoratif menurut penulis cocok diterapkan dalam kasus lingkungan karena cara ini dipandang cukup adil. Kriteria cara ini dipandang adil karena melibatkan pelaku, korban, keluarga mereka dan pihak lain yang terkait dalam suatu tindak pidana, secara bersama-sama mencari penyelesaian terhadap tindak pidana tersebut dan implikasinya, dengan menekankan pemulihan bukan pembalasan.

Pertemuan restoratif memiliki ide yang secara konseptual bisa diterapkan dalam kasus lingkungan karena:

1. Pertemuan restoratif merupakan satu metode yang merefleksikan keadilan yang telah diakui secara universal dan semakin banyak digunakan dalam berbagai kasus pidana di negara maju.

2. Pertemuan restoratif memandang tindak pidana bukan kejahatan terhadap negara/publik melainkan kejahatan terhadap korban. Ini bisa berbentuk perseorangan atau beberapa orang/kelompok.

3. Pertemuan restoratif berfokus pada penderitaan atau kerugian yang diderita oleh korban dan bukan pada pemidanaan terhadap pelaku.

4. Pertemuan restoratif dapat berwujud dialog langsung atau tidak langsung dalam wujud mediasi, rekonsiliasi.

Menurut Supeno ada 5 (lima) prinsip penerapan restorative justice yaitu: a) Membuat pelanggar bertanggung jawab untuk memperbaiki kerugian

${ }^{17}$ Siti Sundari Rangkuti, Hukum Lingkungan dan Kebijaksanaan Lingkungan Nasional, Airlangga Press, Surabaya, 1996, hlm 74. 
yang ditimbulkan untuk memperbaiki kerugian yang ditimbulkan oleh kesalahannya. b) Memberikan kesempatan kepada pelanggar untuk membuktikan kapasitas dan kualitasnya di samping mengatasi rasa bersalahnya. c) Melibatkan para korban orang tua, keluarga. d) Menciptakan forum untuk bekerja sama dalam menyelesaikan masalah. e) Menetapkan hubungan langsung dan nyata antara kesalahan dengan reaksi sosial yang formal. ${ }^{18}$

Kemungkinan menerapkan restorative justice secara yuridis telah diatur dalam Pasal; 84 Undang-Undang No 32 Tahun 2009 Tentang Perlindungan dan Pengelolaan Lingkungan Hidup bahwa:

(1) Penyelesaian sengketa lingkungan hidup dapat ditempuh melalui pengadilan atau di luar pengadilan

(2) Pilihan penyelesaian sengketa lingkungan hidup dilakukan secara suka rela oleh para pihak yang bersengketa.

(3) Gugatan melalui pengadilan hanya dapat ditempuh apabila upaya penyelesaian sengketa di luar pengadilan yang dipilih dinyatakan tidak berhasil oleh salah satu atau para pihak yang bersengketa.

Pasal 84 memberikan pilihan kemungkinan penyelesaian sengketa lingkungan melalui dua model yaitu jalur pengadilan dan di luar pengadilan. Mengenai jalur di luar pengadilan para pihak yang bersengketa dapat memilih bentuk penyelesaian yang dipandang dapat mengakomodir kehendaknya. Dalam Pasal 85 dijelaskan bahwa:

(1) Penyelesaian sengketa lingkungan hidup di luar pengadilan dilakukan untuk mencapai kesepakatan mengenai:

a. bentuk dan besarnya ganti rugi;

b. tindakan pemulihan akibat pencemaran dan/atau perusakan;

c. tindakan tertentu untuk menjamin tidak akan terulangnya pencemaran dan/atau perusakan; dan/atau

${ }^{18}$ Supemo, Hadi, Kriminalisasi Anak, PT Gramedia Pustaka Utama, Jakarta, 2010, hlm 
d. tindakan untuk mencegah timbulnya dampak negatif terhadap lingkungan hidup.

(2) Penyelesaian sengketa di luar pengadilan tidak berlaku terhadap tindak pidana lingkungan hidup sebagaimana diatur dalam UndangUndang ini.

(3) Dalam penyelesaian sengketa lingkungan hidup di luar pengadilan dapat digunakan jasa mediator dan/atau arbiter untuk membantu menyelesaikan sengketa lingkungan hidup.

Pasal 85 ayat (1) memberikan ketentuan bahwa tujuan penyelesaian lingkungan di luar pengadilan adalah untuk mencapai kesepakatan mengenai bentuk dan besaran ganti kerugian, pemulihan akibat pencemaran dan perusakan lingkungan, tindakan tertentu dan tindakan pencegahan agar tidak terulangnya pencemaran dan perusakan. Aturan ini telah mencerminkan semangat restorative justice karena memberikan ruang bagi masyarakat dan pelaku pencemaran dan perusakan lingkungan untuk menyelesaikan sengketa secara sukarela tanpa menuntut ke pengadilan.

Meskipun Pasal 85 ayat (1) memberikan peluang adanya pertemuan restoratif para pihak untuk menyelesaikan kasus lingkungan secara musyawarah, namun dalam Pasal 85 ayat (2) menyatakan "Penyelesaian sengketa di luar pengadilan tidak berlaku terhadap tindak pidana lingkungan hidup sebagaimana diatur dalam Undang-Undang ini". Artinya kasus lingkungan yang dapat diselesaikan dengan cara di luar pengadilan adalah kasus lingkungan perdata, padahal dalam praktek kasus lingkungan cenderung lebih banyak memenuhi unsur pidana, masalah perdata hanya sebagai alternatif penyelesaian saja atau pilihan untuk menuntut ganti rugi padahal secara faktual kasusnya adalah kasus pidana. Ketentuan Pasal 85 ayat (2) ini tidak sesuai dengan penjelasan umum UUPPLH yang bahwa penegakan hukum pidana lingkungan tetap memperhatikan asas ultimum remedium yang mewajibkan penerapan penegakan hukum pidana sebagai upaya terakhir setelah penerapan penegakan hukum administrasi dianggap tidak berhasil. 
Asas ultimum remidium dalam hukum pidana dipandang sebagai sarana hukum terakhir apabila sarana hukum lain tidak dapat menyelesaikan kasus lingkungan, jika Pasal 85 ayat (2) tidak memberlakukan penyelesaian sengketa lingkungan terhadap tindak pidana lingkungan yang diatur dalam UPPLH itu artinya setiap tindak pidana lingkungan harus diselesaikan melalui peradilan pidana dan menutup kemungkinan untuk diselesaikan dengan cara yang lain seperti alternatif penyelesaian sengketa. Hal ini bertentangan dengan asas ultimum remidium yang menuntut hukum pidana seharusnya digunakan di akhir jika proses perundingan (administrasi, perdata alternatif penyelesaian sengketa) tidak berhasil.

Berdasarkan berbagai teori dan fakta-fakta kasus lingkungan yang dikemukakan dalam bab sebelumnya, penulis berpendapat sebaiknya tindak pidana lingkungan yang diatur dalam UPPLH bisa diselesaikan melalui restoratif justice dengan model pertemuan restoratif. Beberapa argumentasi sebagai landasan pemikiran penulis adalah sebagai berikut:

1. Model penyelesaian sengketa lingkungan hidup yang ada saat ini (administrasi, perdata dan pidana) dipandang tidak cukup adil, cenderung menguntungkan pelaku tindak pidana sehingga dipandang tidak efektif, tidak memberikan efek jera, tidak menghasilkan manfaat yang signifikan bagi lingkungan dan masyarakat.

2. Sanksi pidana yang dijatuhkan pengadilan kepada pelaku perorangan maupun korporasi cukup ringan, terdapat beberapa putusan hakim yang dijatuhkan di bawah standar minimum yang ditentukan dalam UUPPLH, tidak menimbulkan daya jera dan menyebabkan tingkat recidive untuk kasus lingkungan.

3. Gugatan perdata yang dikabulkan pengadilan tidak sesuai dengan nilai kerugian materiil yang diderita korban dan sulit untuk dieksekusi karena tergugat tidak mau melaksanakan putusan pengadilan.

4. Sanksi administrasi yang dipandang bisa efektif dan efisien karena tidak perlu ada putusan pengadilan, dalam praktik tidak berjalan sesuai harapan karena dalam pelaksanaannya minim pengawasan dari 
Pemerintah Daerah atau Dinas Lingkungan terkait sehingga sanksi administrasi tidak dilaksanakan atau dilaksanakan sebagian dan terjadi pengulangan pencemaran atau perusakan lingkungan.

5. Model pertemuan restoratif menawarkan ide pemulihan, perbaikan lingkungan yang memberikan manfaat bagi masyarakat maupun lingkungan bukan penghukuman yang selama ini tidak menghasilkan keadilan dan kemanfaatan dalam penegakan hukum pidana lingkungan.

b. Akibat Hukum Penerapan Restorative Justice Terhadap Status Tindak Pidana Lingkungan Hidup untuk Mengurangi Penumpukan Perkara dan Menghindari Sanksi Pidana

Persoalan yang menjadi perdebatan terkait penerapan model pertemuan restoratif dalam menanggulangi kasus tindak pidana lingkungan adalah masalah akibat hukum pertemuan restoratif terhadap status perkara lingkungan apabila perundingan itu mencapai kesepakatan. Mungkinkah hasil kesepakatan berupa perdamaian akan menghentikan perkara lingkungan. Masalah akibat hukum model pertemuan restoratif ini menjadi pertanyaan masyarakat dan penegak hukum.

Akibat hukum adalah akibat yang ditimbulkan oleh peristiwa hukum, peristiwa hukum disebabkan oleh perbuatan hukum, sedangkan suatu perbuatan hukum dapat melahirkan suatu hubungan hukum, maka akibat hukum juga dapat dimaknai sebagai suatu akibat yang ditimbulkan oleh adanya suatu perbuatan hukum dan/atau hubungan hukum. ${ }^{19}$ Menurut Syarifin akibat hukum merupakan segala akibat yang terjadi dari segala perbuatan hukum yang dilakukan oleh subyek hukum terhadap obyek hukum atau akibat-akibat lain yang disebabkan karena kejadian-kejadian tertentu oleh hukum ditentukan atau dianggap sebagai akibat hukum. ${ }^{20}$

Dalam hukum acara pidana yang diatur dalam Kitab Undang-Undang Hukum Pidana (KUHAP) penyidik memiliki kewenangan untuk menghentikan

${ }^{19}$ Ishaq, Dasar-dasar Ilmu Hukum, Sinar Grafika, Jakarta, 2008, hlm 86.

${ }^{20}$ Syarifin, Pengantar Ilmu Hukum, CV Setia, Bandung, 2009, hlm 71. 
proses penyidikan suatu tindak pidana apabila memenuhi syarat yuridis yang diatur dalam Pasal 109 ayat (2) KUHAP yaitu:

1. Tidak memperoleh bukti yang cukup

2. Peristiwa yang disangkakan bukan merupakan tindak pidana

3. Penghentian penyidikan demi hukum. Alasan ini dapat dipakai apabila ada alasan- alasan hapusnya hak menuntut dan hilangnya hak menjalankan pidana, yaitu antara lain karena nebis in idem, tersangka meninggal dunia, atau perkara pidana telah melewati masa daluwarsa.

Meski syarat melakukan penghentian penyidikan telah diatur dalam Pasal 109 ayat (2) KUHAP tetapi ada ruang bagi penyidik untuk melakukan tindakan hukum lain. Sebagaimana yang telah disebutkan Pasal 16 huruf poin 1 bahwa kewenangnya adalah dapat "mengadakan tindakan lain menurut hukum yang bertanggung jawab”. Berkaitan dengan penghentian penyidikan kepolisian memiliki kewenangan untuk bertindak berdasarkan penilainnya sendiri, kewenangan ini disebut diskresi. yang dimaksud bertindak menurut penilaiannya sendiri adalah suatu tindakan yang dapat dilakukan oleh anggota Kepolisian yang mempertimbangkan manfaat serta risiko dari tindakannya dan betul-betul untuk kepentingan umum. Seorang pejabat Polri dapat menerapkan diskresi dalam berbagai kejadian yang dihadapinya sehari-hari tetapi berbagai literatur tentang diskresi lebih memfokuskan kepada penindakan selektif (selective enforecement) yaitu berkaitan dengan faktor-faktor yang mempengaruhinya apakah seorang pelanggar hukum akan ditindak atau tidak

Kewenangan dalam melakukan tindakan lain menurut hukum yang bertanggungjawab sebagaimana disebutkan dalam Pasal 16 Ayat (1) huruf 1 dapat dilaksanakan oleh penyelidik atau penyidik dengan syarat:

1. Tidak bertentangan dengan suatu aturan hukum.

2. Selaras dengan kewajiban hukum yang mengharuskan tindakan tersebut harus dilakukan.

3. Harus patut, masuk akal, dan termasuk lingkungan jabatannya.

4. Pertimbangan yang layak berdasarkan keadaan yang memaksa. 
5. Menghormati hak asasi manusia.

Kewenangan bertindak menurut penilaian penyidik sebagaimana disebutkan dalam Pasal 16 ayat (1) huruf 1 memberikan kemungkinan bagi penyidik untuk dapat melakukan tindakan hukum berupa penghentian penyidikan terhadap status perkara lingkungan yang telah dilakukan mediasi melalui pertemuan restoratif sepanjang tindakan hukum lain yang dimaksud betul-betul dihasilkan dari kesepakatan antara para pihak untuk melakukan tindakan tertentu yang diarahkan pada upaya pemulihan lingkungan. Tindakan lain tersebut harus dapat dipertanggungjawabkan oleh penyidik dengan alasan-alasan yang layak, dan masuk akal untuk memberikan keadilan bagi korban dan lingkungan.

Untuk kewenangan bertindak menurut penilaiannya sendiri (diskresi) dapat dilakukan dalam keadaan: ${ }^{21}$

1. Keadaan yang sangat perlu.

2. Tidak bertentangan dengan perundang-undangan.

3. Tidak bertentangan dengan kode etik kepolisian.

Menurut ketentuan di atas dapat dikatakan bahwa kesepakatan yang terjadi dalam pertemuan restoratif menimbulkan akibat hukum berupa penghentian penyidikan terhadap perkara lingkungan yang telah diselesaikan dengan model pertemuan restoratif. Penghentian penyidikan didasarkan pada kewenangan penyidik melakukan tindakan hukum lain menurut hukum yang bertanggung jawab. Tindakan penghentian penyidikan ini harus diimbangi dengan pembayaran ganti kerugian dan/atau tindakan pemulihan lingkungan atau tindakan mencegah dampak negatif dari kegiatan usaha. Jadi kewenangan penyidik menghentikan perkara lingkungan atas dasar kesepakatan para pihak dalam pertemuan restoratif harus dipandang sebagai kebijakan yang sesuai dengan hukum dan kebijakan yang memberikan nilai keseimbangan restoratif bagi pelaku, korban dan lingkungan.

${ }^{21}$ Shela Franita, Dasar Kewenangan Penyidik Menghentikan Proses Penegakan Hukum Kecelakaan Lalu

Lintas, Makalah, Dipresentasikan di Fakultas Hukum Universitas Bengkulu, 2014, hlm. 43. 
Meskipun kesepakatan dalam pertemuan restoratif dapat menghentikan status perkara lingkungan secara yuridis-normatif tindakan penghentian penyidikan yang tidak mengikuti ketentuan Pasal 109 ayat (2) KUHAP dipandang bertentangan dengan hukum acara pidana karena aturan tersebut tidak mengatur bahwa hasil kesepakatan mediasi atau pertemuan restoratif sebagai alasan dapat dihentikannya penyidikan. Kebijakan penghentian penyidikan atas dasar kesepakatan para pihak dianggap menyimpang dari hukum acara dan secara hukum legitimasi kekuatan eksekusinya dapat dipersoalkan.

Upaya penyelesaian perkara pidana termasuk tindak pidana lingkungan saat ini belum ada aturan yang secara tegas, namun Kepala Badan Reserse Kriminal (Kabareskrim) Polri pada tahun 2012 telah mengeluarkan Surat Telegram Kabareskrim Nomor: STR/583/VIII/2012 tanggal 08 Agustus 2012 tentang Penerapan Restorative Justice, surat telegram tersebut yang dijadikan dasar penyidik dalam penyelesaian perkara pidana dengan keadilan restoratif, sehingga muncul Surat Edaran Kapolri Nomor 8 tahun 2018 (SE/8/VII/2018 tanggal 27 Juli 2018) tentang Penerapan Keadilan Restoratif (restorative Justice) Dalam Penyelesaian Perkara Pidana. Surat edaran Kapolri tentang Restorative Justice ini yang selanjutnya dijadikan landasan hukum dan pedoman bagi penyelidik dan penyidik Polri yang melaksanakan penyelidikan/ penyidikan, termasuk sebagai jaminan perlindungan hukum serta pengawasan pengendalian, dalam penerapan prinsip keadilan restoratif (restorative justice) dalam konsep penyelidikan dan penyidikan tindak pidana demi mewujudkan kepentingan umum dan rasa keadilan masyarakat, sehingga dapat mewujudkan keseragaman pemahaman dan penerapan keadilan restoratif (restorative justice) di Lingkungan Polri.

Pelaksanaan kewenangan penyelidikan dan/atau penyidikan tindak pidana oleh Penyidik Polri yang menerapkan prinsip keadilan restoratif (restorative justice) dalam metode penyidikannya dapat didasarkan pada ketentuan sebagai berikut: 
1. Pasal 7 ayat (1) huruf J Undang Undang No. 08 tahun 1981 tentang Hukum Acara Pidana, bahwa penyidik karena kewajibannya mempunyai wewenang mengadakan tindakan lain menurut hukum yang bertanggung jawab;

2. Pasal 16 ayat (1) huruf L dan Pasal 18 Undang Undang Nomor 2 tahun 2002 tentang Kepolisian Negara Republik Indonesia dan Pasal 5 ayat (1) angka 4 Undang Undang No 8 tahun 1981 tentang Hukum Acara Pidana bahwa tindakan lain sebagaimana dimaksud dalam Pasal 16 ayat (1) huruf $\mathrm{L}$ adalah tindakan penyelidikan dan penyidikan yang dilaksanakan jika memenuhi syarat sebagai berikut:

a. Tidak bertentangan dengan suatu aturan hukum;

b. Selaras dengan hukum yang mengharuskan tindakan tersebut dilakukan;

c. Pertimbangan yang layak berdasarkan keadaan yang memaksa;

d. Harus masuk akal, patut, dan termasuk dalam lingkungan jabatannya, dan;

e. Menghormati hak asasi manusia (HAM).

3. Pasal 18 Undang Undang Nomor 2 tahun 2002 tentang Kepolisian Negara Republik Indonesia, bahwa untuk kepentingan umum pejabat Kepala Kepolisian Negara Republik Indonesia dalam melaksanakan tugas dan wewenangnya dapat bertindak menurut penilaiannya sendiri. Pasal 18 ayat (2) Undang Undang Nomor 2 tahun 2002 tentang Kepolisian Negara Republik Indonesia sebagaimana dimaksud dalam Pasal 18 ayat (1) hanya dapat dilakukan dalam keadaan sangat perlu dengan memperhatikan undangundang serta Kode Etik Profesi Polri.

4. Pasal 22 ayat (2) huruf b dan c Undang Undang Nomor 30 tahun 2014 tentang Administrasi Pemerintahan dinyatakan bahwa setiap penggunaan diskresi pejabat pemerintahan bertujuan untuk mengisi kekosongan hukum dan memberikan kepastian hukum.

Untuk menentukan akibat hukum model pertemuan restoratif justice dalam

Surat Edaran Kapolri No 8 Tahun 2018 Tentang Pedoman penanganan 
Penyelesaian perkara dengan pendekatan restorative justice memberikan acuan bagaimana akibat hukum kasus yang di selesaikan secara restorative justice yaitu:

1. Terpenuhi syarat materiil, yaitu:

a. Tidak menimbulkan keresahan masyarakat dan tidak ada penolakan masyarakat;

b. Tidak berdampak konflik sosial;

c. Adanya pernyataan dari semua pihak yang terlibat untuk tidak keberatan, dan melepaskan hak menuntutnya di hadapan hukum;

d. Prinsip pembatas;

I. Pada pelaku: Tindak kesalahan pelaku relatif tidak berat, yakni kesalahan (schuld) atau mensrea dalam bentuk kesengajaan (dolus atau opzet) terutama kesengajaan sebagai maksud atau tujuan (opzet als oogmerk); dan Pelaku buka residivis.

II. Pada tindak pidana dalam proses: Penyelidikan; dan Penyidikan sebelum SPDP dikirim ke Penuntut Umum.

2. Terpenuhi syarat formil, yaitu:

a. Surat permohonan perdamaian kedua belah pihak (pelapor dan pelapor);

b. Surat Pernyataan Perdamaian (akte dading) dan penyelesaian perselisihan para pihak yang berperkara (pelapor dan/atau keluarga pelapor, terlapor dan/atau keluarga terlapor, dan perwakilan dari tokoh masyarakat) diketahui oleh atas penyidik;

c. Berita Acara Pemeriksaan tambahan pihak yang berperkara setelah dilakukan penyelesaian perkara melalui keadilan restoratif (restorative justice);

d. Rekomendasi gelar perkara khusus yang menyetujui penyelesaian keadilan restoratif (restorative justice);

e. Pelaku tidak keberatan atas tanggungjawab, ganti rugi, atau dilakukan dengan sukarela;

f. Semua tindak pidana dapat dilakukan restorative justice terhadap kejahatan umum yang tidak menimbulkan korban manusia. 
Menganalisis tindak pidana lingkungan dengan menerapkan syarat materiil dan formil yang diatur dalam Surat Edaran Kapolri tidak memungkinkan untuk dihentikan melalui Surat Perintah Penghentian Penyidikan (SP3). Argumentasi yang digunakan untuk menganalisisnya adalah:

1. Dilihat dari syarat materil, tindak pidana lingkungan umumnya menimbulkan keresahan dan berdampak sosial bagi masyarakat yang terdampak dan dalam penyelesaian masyarakat sebagai korban meminta tanggung jawab yang sepadan dengan tingkat kerusakan atau pencemaran, namun perusahaan biasanya tidak bersedia bertanggung jawab mengganti kerugian atau hanya mengganti sebagian saja. Tidak dipenuhinya tuntutan masyarakat atau bila perusahaan keberatan memberikan ganti rugi seringkali menimbulkan konflik sosial yang berkepanjangan sehingga mereka meminta pemerintah untuk menutup dan mencabut izin perusahaan. Terkait dengan prinsip pembatas dalam syarat materil, tindak pidana lingkungan biasanya dilakukan dengan sengaja sebagai maksud untuk mencapai tujuan sehingga tingkat kesalahan dapat terlihat jelas.

2. Dilihat dari syarat formil, penulis berpendapat terpenuhi atau tidaknya syarat formil tergantung pada dipenuhi atau tidaknya syarat materil, karena para pihak akan bersedia mengajukan permohonan perdamaian, menandatangani surat pernyataan perdamaian (akte dading), Berita Acara Pemeriksaan tambahan penyelesaian perkara restoratif. Apabila para pihak telah mencapai kesepakatan dan tidak ada keberatan mengenai kewajiban membayar ganti rugi atau tindak pemulihan fungsi lingkungan. Uraian di atas memberikan gambaran bahwa tindak pidana lingkungan yang diselesaikan melalui model pertemuan restoratif menimbulkan akibat hukum berupa penghentian penyidikan terhadap status perkara sepanjang memenuhi syarat materil dan formil yang diatur dalam Surat Edaran Kapolri No 8 Tahun 2018 Tentang Pedoman penanganan Penyelesaian Perkara dengan pendekatan restorative justice. Penyidikan berdasarkan Pasal 16 ayat (1) huruf L UndangUndang Kepolisian dapat melakukan tindakan lain sepanjang memenuhi syarat 
yang ditentukan dalam peraturan perundang- undangan. Dalam kasus lingkungan seperti yang terjadi di Kecamatan Rancaekek, Jawa Barat Selatan dan Kabupaten Sukoharjo meninggalkan kesusahan dan penderitaan bagi masyarakat, upaya mediasi pernah dilakukan tetapi perusahaan tidak membayar seluruh ganti rugi sehingga masyarakat keberatan dan menuntut pemerintah menutup izin operasional perusahaan. Jadi sulit memenuhi syarat materil seperti diatur dalam Surat Edaran Kapolri karena korban tindak pidana lingkungan bukan individu tetapi masyarakat. Mengkondisikan korban individu untuk memberikan pemaafan dan perdamaian jauh lebih mudah dibandingkan dengan masyarakat.

Kemungkinan terpenuhinya syarat materil bisa terjadi apabila tindak pidana lingkungan relatif ringan. Dikatakan ringan bisa diukur dari tingkat kerusakan tidak berdampak luas bagi lingkungan, tidak menimbulkan korban jiwa atau keadaan yang membahayakan kesehatan masyarakat setempat, mudah dipulihkan, diancam dengan pidana minimal 3 (tiga) bulan penjara atau denda tujuh ribu lima ratus rupiah. ${ }^{22}$ Kualitas dan kuantitas korban menjadi tolak ukur tindak pidana lingkungan kategori berat/ringannya tindak pidana lingkungan. Semakin ringan maka semakin mudah untuk diambil tindakan penghentian penyidikan, sebaliknya semakin berat maka semakin sulit diselesaikan secara restoratif.

\section{PENUTUP}

Model Restorative Justice yang dimungkinkan dapat diterapkan dalam penegakan hukum pidana untuk menanggulangi tindak pidana lingkungan hidup adalah model Pertemuan Restoratif (Restorative Conferencing), sebuah model yang membutuhkan partisipasi dari pelaku (individu/korporasi), korban (masyarakat dan lingkungan), mediator, penyidik Polri dan PPNS secara sukarela untuk mencari kesepakatan perdamaian. keberhasilan model pertemuan restoratif berupa kesepakatan sebagai upaya konkrit dalam rangka menjamin kelestarian lingkungan dan

${ }^{22}$ Lihat Pasal 205 ayat (1) KUHAP 
mewujudkan keadilan ekologis. Kesepakatan model ini dapat berupa: (a) Ganti kerugian kepada masyarakat (b) Tindakan pemulihan lingkungan yang mengalami kerusakan/pencemaran (c) Tindakan tertentu untuk mencegah perusakan/ pencemaran (d) Tindakan pencegahan timbulnya dampak negatif terhadap lingkungan hidup. Sebaliknya bila pertemuan restoratif mengalami kegagalan maka korban (individu/masyarakat/organisasi lingkungan) dapat melaporkan kepada pihak yang berwena untuk diselesaikan melalui pengadilan supaya diproses secara pidana.

Penerapan restorative justice dengan model pertemuan restoratif (Restorative Conferencing), menimbulkan akibat hukum terhadap status perkara tindak pidana lingkungan berupa penghentian penyidikan untuk menghindari sanksi pidana dan mengurangi penumpukan perkara melalui diskresi penegak hukum sepanjang memenuhi syarat materil dan formil yang diatur dalam Surat Edaran Kapolri No 8 Tahun 2018 Tentang Pedoman Penanganan Penyelesaian Perkara dengan Pendekatan Restorative Justice, tetapi tindak pidana lingkungan umumnya menimbulkan kerugian ekonomi dan ekologis serta konflik sosial yang menyulitkan penegak hukum memenuhi kedua syarat tersebut. Pemenuhan syarat ini bertujuan agar tidak memunculkan keberagaman administrasi penyelidikan/penyidikan dan perbedaan interpretasi para penyidik serta penyimpangan dalam pelaksanaannya.

Hal tersebut menunjukkan bahwa perlu adanya model pertemuan restoratif (Restorative Conferencing) sebuah model penyelesaian sengketa lingkungan di luar pengadilan sebaiknya menjadi pilihan utama bagi penegakan hukum untuk meminta pertanggungjawaban pelaku tindak pidana lingkungan dengan meminta bantuan mediator sebagai wasit yang menampung keinginan para pihak. Keuntungan menerapkan model ini penegakan hukum pidana lingkungan dapat dilaksanakan secara efisien dan berorientasi pada pengembalian kondisi korban seperti semula berupa ganti kerugian dan/atau tindakan pemulihan lingkungan yang rusak/tercemar sebagai wujud keadilan ekologis. Menerapkan pertemuan restoratif dalam konteks penyelesaian tindak pidana lingkungan hidup adalah bertujuan untuk memberikan jaminan pengembalian kelestarian fungsi lingkungan hidup dan menempatkan hukum pidana sebagai ultimum remidium bukan sarana hukum yang bersifat primum remidium. 
Eksistensi keadilan restoratif saat ini dilaksanakan melalui diskresi penegak hukum sehingga untuk masa mendatang diperlukan adanya pengaturan dalam hukum acara secara limitatif terkait jenis tindak pidana yang dapat diselesaikan melalui restoratif sehingga memberikan kepastian tentang batasan tindak pidana yang dapat diselesaikan secara restorative justice. Kasus lingkungan sebaiknya dimasukkan sebagai tindak pidana yang bisa diselesaikan secara restorative justice supaya berakibat hukum pada penghentian penyidikan diikuti tanggung jawab membayar ganti kerugian dan tindak pemulihan lingkungan sebagai alternatif menghindari sanksi pidana dan penumpukan perkara di pengadilan tantangan yang dihadapi di masa yang akan datang adalah bagaimana caranya memberikan perlindungan kepada debitur, apakah kriteria yang dipergunakan untuk menertibkan klausul eksonerasi dalam perjanjian baku tersebut. Dalam hal ini yang dapat berperan adalah badan pembentuk undang-undang, pemerintah, pengadilan, notaris dan konsultan hukum. Pembentuk undang-undang disarankan untuk memikirkan pengaturan klausul eksonerasi dalam perjanjian baku, pemerintah harus melakukan pengawasan terhadap diberlakukannya klausul eksonerasi untuk menjamin kepentingan-kepentingan debitur.

Bagi para konsultan hukum dalam hal ini adalah memberikan nasihat hukum kepada para pihak tentang klausul eksonerasi yang terdapat di dalam suatu perjanjian yang diinginkan oleh para pihak dan menerangkan ketidakseimbangan diantara para pihak dan resiko yang dihadapi mereka. Notaris berkewajiban sesuai dengan kode etiknya untuk menanyakan kepada para pihak apakah mereka telah memahami klausul eksonerasi dalam hal klausul itu tercantum dalam perjanjian yang akan diadakan oleh para pihak. 


\section{DAFTAR ISI}

\section{A. Buku}

Absori, Hukum Lingkungan dan Pemberdayaan Masyarakat, Makalah Seminar Legal Hermeneutics Sebagai Alternatif Kajian Hukum, Makalah FH Undip, 24 November 2007.

Ishaq, Dasar-dasar Ilmu Hukum, Sinar Grafika, Jakarta, 2008.

Marshall, Tony F. Retorative Justice an Overview. Home Office, Information \& Publications Group London.

Eva Achjani Zulfa, Pergeseran Paradigma Pemidanaan, Lubuk Agung, Bandung, 2011.

Phillipe Nonet dan Philip Selznick, Law and Society Transition, Harper \& Row, New York, 1978.

Sudharto P Hadi dan Adji Samekto, Dimensi Lingkungan dalam Bisnis Kajian Tanggung Jawab Sosial Perusahaan pada Lingkungan, Badan Penerbit Undip Semarang, 2007.

Siti Sundari Rangkuti, Hukum Lingkungan dan Kebijaksanaan Lingkungan Nasional, Airlangga Press, Surabaya, 1996.

Supemo, Hadi, Kriminalisasi Anak, PT Gramedia Pustaka Utama, Jakarta, 2010.

Syarifin, Pengantar Ilmu Hukum, CV Setia, Bandung, 2009.

\section{B. Jurnal/Makalah}

Anna Ningsih, Pemukiman Kembali, Alternatif Ganti Kerugian bagi Masyarakat Korban Penggusuran, Jurnal Hukum Vol XXXI No 3 Juli Semarang, 2003.

Artidjo Alkostar, Restorative Justice, (Varia Peradilan ke XXII N. 262, IKAHI. Jakarta. Tanpa Tahun.

Bagir Manan, Restorative Justice (Suatu Perkenalan), Majalah Hukum Varia Peradilan, Tahun XXI No. 247 Juni 2006.

Edi Setiadi, Sistem Peradilan Pidana, Materi Kuliah S2 Unisba, Bandung, 2016.

Setyo Utomo, Sistem Pemidanaan Dalam Hukum Pidana Yang Berbasis Restorative Justice: Majalah Hukum Nasional Nomor 01 Tahun BPHN), Jakarta, 2011.Muhammad Akib, Wewenang Kelembagaan Pengelolaan 
Lingkungan Hidup di Era Otonomi Daerah, Jurnal Media Hukum UMY Vol. 19 No 2 Desember 2012.

Satjipto Rahardjo, Hukum Progresif Hukum yang Membebaskan, Jurnal Hukum Progresif, Program Doktor Ilmu Hukum Undip, Semarang, 2005.

Siti Sundari Rangkuti, Kesamaan Persepsi Terhadap Penegakan Hukum Lingkungan, Majalah FH Unair, No 5 Tahun IX Oktober 1994.

Shela Franita, Dasar Kewenangan Penyidik Menghentikan Proses Penegakan Hukum Kecelakaan Lalu Lintas, Makalah, Dipresentasikan di Fakultas Hukum Universitas Bengkulu, 2014.

\section{Peraturan Perundang-undangan}

Undang-Undang No 32 Tahun 2009 Tentang Perlindungan dan Pengelolaan Lingkungan Hidup

Undang-Undang No 12 Tahun 2011 Tentang Pembentukan Peraturan Perundangundangan

Undang-Undang No 48 Tahun 2009 Tentang Kekuasaan Kehakiman 